\author{
Lidija Rezoničnik \\ Department of Slavistics, Faculty of Arts, \\ Department of Slavistics and Department \\ of Comparative Literature and Literary Theory \\ University of Ljubljana \\ Ljubljana \\ Lidija.Rezonicnik@ff.uni-lj.si
}

\title{
The Image of Slovenes and Gottschee Germans in the Historical Novel Rebellion in der Gottschee
}

\begin{abstract}
The paper surveys the literature of the Gottschee Germans, former inhabitants of the Gottschee region in Slovenia. It begins by summarizing the history and literary works of the Gottschee Germans, and secondly it deals with the historical novel Rebellion in der Gottschee by Karl Rom. The novel was published in 1938 in German. It focuses on the great peasant revolt in Slovenia (Carniola) that took place in 1515. The revolt was organized by the inhabitants of the Gottschee area against the violent landlord and was soon supressed. Based on image studies (imagology), the paper analyses the portrayal of the Slovenes and Gottschee Germans and discusses how Slavs (Slovenes) and Germans (Gottschee Germans) are represented in the novel.
\end{abstract}

Keywords: Gottschee Germans, Rebellion in der Gottschee, Karl Rom, historical novel, great peasant revolt 1515, imagology, auto-image, hetero-image.

This is an Open Access article distributed under the terms of the Creative Commons Attribution 3.0 PL License (creativecommons.org/licenses/by/3.0/pl/), which permits redistribution, commercial and non-commercial, provided that the article is properly cited. ๑ The Author(s), 2018 Publisher: Institute of Slavic Studies, Polish Academy of Sciences

Editor-in-chief: Jolanta Sujecka

Conception and academic editing of this issue: Maciej Falski, Tomasz Rawski, Jolanta Sujecka with the collaboration of Ewa Niedziałek 


\section{The Region of Gottschee (Kočevska) and the Gottschee Germans}

T there had been a German-speaking population living in Slovene lands ever since the late Middle Ages. At the end of the 10th century these German residents ${ }^{1}$ were living primarily in towns and cities, e.g. Maribor, Celje and Ptuj. The end of the 13th century was followed by a wave of socalled "rural colonization", when the land barons resettled the Germanspeaking peasant population from Tirol (present-day Austria) to the relative wilderness of the north-western part of Slovenia (Selška dolina/Selca valley/Selzachertal) and in the 14th century from east Tirol and Carinthia (present-day Austria) to the south-eastern part of the country (Kočevje/ Gottschee). A third German-speaking community, living in the north-east corner of modern Slovenia, in Apaško polje/Apače valley/Abstall, as well as in four other German-speaking villages in Prekmurje/“Over-Mura-region" (Fikšinci, Kramarovci, Ocinje and part of Serdica) (T. Ferenc, 2002, p. 156), was cut off from the former Germanic territory after the fall of the AustroHungarian Empire and the conclusion of the Treaty of Saint-Germain-enLaye in 1919 (M. Ferenc, 2005, pp. 13-16; Moric, 2016b, p. 88).

The Gottschee area was remote and was covered by karstic land and a forested landscape, making it very sparsely inhabited, but certain parts were nonetheless settled by Slovenians (or Slavs at least) back in the 13th century, before the arrival of the German colonists. The counts of Ortenburg, a noble Carinthian family that at the time had a tract of land in contemporary Carniola, ${ }^{2}$ then began to resettle farmers from east Tirol and Carinthia in the early 14 th century. Their motive for this was economic, as working a larger amount of land would increase the family's profits. The newcomers felled the trees and thus acquired new land to plough. They moved to already inhabited areas and established new settlements, while Kočevje itself became the centre and hub of the region. The territory of German inhabitation in the Gottschee region, the German word for the area roughly equivalent to the modern-day wider Kočevska region, encompassed around 800 square kilometres, and it bears emphasizing that the Slovenian- and

\footnotetext{
1 This article uses the terms Slovenian/German for language and population in the broadest possible sense, indicating those who spoke a Slavic and Germanic language in the territories being considered. They are not used in their nationalistic sense, i.e. to refer to the specific countries of Slovenia and Germany, as these political concepts took hold at a later period than the one in the novel under examination.

2 Carniola is a historical name given to the administrative or political entity that encompassed the greater part of modern Slovenia under the Habsburg empire (Dolinar\& Knop, 2003, p. 536).
} 


\section{Lidija Rezoničnik}

German-speaking populations did not reside separately; they lived side by side all the way until the rise of Nazism and the emigration of the Gottschee Germans in the years 1941 and 1942. First they resettled to eastern Slovenia (the vicinity of Brežice/Rann) on the basis of an agreement between Nazi Germany and fascist Italy (Hitler-Mussolini plan), and after the end of World War II moved on to Austria, Germany, America and Canada (M. Ferenc, 2005, pp. 19-196; Moric, 2016a, pp. 103-104). Only a handful of Germans remained in Gottschee after WWII; census records from 1953 make note of around 120 residents who were of German/Austrian nationality or who spoke German as their native language, while there were fewer than 20 such individuals in 1991 (M. Ferenc, 2005, pp. 292, 293).

These days the former Gottschee inhabitants now live around the world in diasporas. ${ }^{3}$ They preserve the memory of their homeland, or the homeland of their ancestors, through the work of various associations and organizations, by hosting events, and by publishing newspapers and other writings. Gottschee, its motifs and its themes are also the subject of many works of literature, both poetry and prose (especially memorialist prose). These works have been published as books, for instance the novel discussed in the present paper, or in journals and newsletters (poems and short prose texts in Gottscheer newspapers). Some are written homages to or memoirs of the former homeland, and some present emigration and the beginnings of life in the diaspora within the intimate environment of a family (children and grandchildren), so they give background information about the family's history or origins.

The continuation of this paper is a treatment of the novel Rebellion in der Gottschee, which was published in 1938, before the resettlement of the Gottscheers from the Gottschee area in 1941/1942. Due to poor conditions and poverty, as well as for reasons of work or study, emigration from the region already occurred in the second half of the 19th and first half of the 20 th century. Among those who moved before World War II was also the novel's author, Karl Rom.

\section{Rebellion in der Gottschee}

The novel Rebellion in der Gottschee (Revolt in Gottschee) deals with the Gottschee peasant uprising at the beginning of the 16th century. Gottschee

"Diaspora" refers to an ethnic or national community living within the territory of a different nation or state. Usually they have experienced forced or voluntary emigration from their homeland, and an essential part of diaspora members' identity is in their memory of their "lost homeland", which leads to this identity being preserved over a long span of time (cf. Moric, 2014, p. 83). 
and the Gottschee Germans figure prominently in the novel. The book was written by Karl Rom (1902-1963), a Gottschee German who was born in the region's town of Unterdeutschau (Nemška Loka). After graduating from school in Ljubljana in 1920 he moved to Graz, where he finished studying medicine, going on to work as a doctor in Austrian Carinthia and then later in Vienna. With some kindred spirits he founded the Socialist Association of Doctors in Austria (Sozialistische Ärztevereinigung Österreichs) and was its first president (1945-1950) (Neugebauer\& Schwarz, 2005, p. 220). Extant sources mention Karl Rom primarily in his capacity as a doctor, while his literary efforts garner fewer mentions. Available information (e.g. "Österreichische Nationalbibliothek", n.d.) indicate that Rom was the author of a number of medical articles, although only the presently discussed work is listed with him as its author. His novel was published by Amalthea Verlag in 1938, as part of the Auslanddeutsches Schrifttum, or "literature by foreign citizens of German ethnicity".

A literary dictionary of German history in German prose (Deutsche Geschichte in deutscher Erzählung) places Rom's novel among works that thematize the peasant uprising and, given the chronotope, lists it as pertaining to what were Austrian lands at the time (Carinthia, Styria, Tirol) (Luther, 1943, p. 118). A project on German historical novels ("Projekt Historischer Roman", n.d. ${ }^{4}$ ) listed the following keywords next to Rom's work: peasant revolt 1515, Friedrichstein, Gottschee, beginning of the 16th century, Carniola, Austria, Styria. There appear not to be any literary discussions about the novel that can be found from German-speaking areas. Both Karl Rom and his work are also rarely mentioned in Slovenian territory. Slovenian libraries only hold three copies of his novel, which is otherwise mentioned in a few discussions from Slovenian authors (Hladnik, 2009 on the Slovenian historical novel; Kordiš, Petrovič, \& Jerbič Perko, 2015 - in documentation for an exhibition on the peasant revolt of 1515; Moric, 2017 - in documentation for an exhibition on the residents of Gottschee), but it is not examined in detail in any literary studies. The aforementioned discussions (Kordiš et al., 2015, p. 27) describe Rebellion in der Gottschee as the first Gottschee historical novel, while German sources mark it as "an author's memoir of the existential struggle of Germans in Gottschee”. ${ }^{5}$

\footnotetext{
4 Projekt historischer Roman was a project run by Günter Mühlberger and Kurt Habitzel at the Department of German Studies at the University of Innsbruck; it came to a close in 1997. The project saw, among other things, the creation of an online database with information on German historical novels, keywords, information on libraries where books were held, and possible secondary sources on the novels.

5 Roman "in dem er [Karl Rom] dem Existenzkampf der Deutschen des Gottscheer Landes ein schriftstellerisches Denkmal setzte” (Neugebauer\& Schwarz, 2005, p. 220).
} 


\section{|| Lidija Rezoničnik}

The novel is written in German in Gothic script, which was the predominant style of writing used in Central and Western Europe; it was used in Germanophone areas until the 1940s (Janko \& Otorepec, 1989, pp. 317-318). The book was not reprinted, and it was not translated into Slovenian or any other languages. In terms of structure, the novel Rebellion in der Gottschee is divided into a preface, followed by eight chapters, with a few explanations and a dictionary of some Gottschee words at the end. ${ }^{6}$ In the preface (Rom, 1938, pp. 7-12) the narrator quotes a section from Slava vojvodine Kranjske (Die Ehre des Herzogthums Crain) ${ }^{7}$ ) which paints a picture of how the Ortenburg counts resettled 300 men with their families from what was part of modern Austria to Gottschee, namely an area that, until their colonization in the 14th century, had been completely overgrown with old growth forest and that only began to be cleared and tilled for farming upon their arrival. After the Ortenburg counts faded from power the area was taken over by the counts of Celje, and it changed hands once again in the 15th century, falling under the control of the Habsburg monarchy. Around this time the devastating Turkish attacks began, which ravaged the countryside. Droughts and the resulting poor crops also plagued the farmers, who were further burdened by high taxes and tolls, and the narrator concludes that it was therefore only logical that in 1515 the farmers joined together to revolt against the noble landholders. Despite their difficult life and the increasing rate of emigration, especially of intellectuals, the Gottschee farmers stayed in their land, the narrator explains, and at the time of the novel's writing they numbered around 15,000 and from the time of their arrival onwards they made up a "small German drop in a Slavic sea". ${ }^{8}$ In his concluding explanations the author remarks that the Gottschee German dialect was "primeval and riddled with archaic phrases", ${ }^{9}$ and goes on to explain some toponyms and oeconyms, along with some special and common Gottschee words, such as ammo (mom) and atte (dad).

\footnotetext{
6 The German population in Gottschee (except in the town of Kočevje, where primarily High German was spoken) communicated among themselves in Göttscheabarisch, i.e. the Gottschee dialect, which has many elements of the medieval speech of eastern Tirol and Carinthia, whence the Gottschee Germans came, as well as some elements of Slavic languages (cf. Moric, 2016a, p. 107).

7 The Glory of the Duchy of Carniola was written in German by Baron Janez Vajkard Valvasor and was published in 1689 in Nuremberg. The tome comprises 15 books totalling 3, 532 pages. In it Valvasor included a historical, geographical and ethnological account of events in the then country of Carniola, accompanied by illustrations (copper engravings). It serves as an important historical document to the present day (Reisp, n.d.).

8 “einen kleinen deutschen Volkssplitter mitten im slawischem Meere" (Rom, 1938, p. 7).

9 "kernig und voll altertümlicher Wendungen" (Rom, 1938, p. 320).
} 
The novel's narrative is based on a historical event, the peasant revolt, which occurred in 1515 on lands within Slovenia's modern borders, in an area that in the 16th century belonged to the German Holy Roman Empire and was ruled by an elected emperor from the Habsburg dynasty. The majority farmer population of the region (according to Kordiš et al., 2015 , pp. 3-29, around the year 1500 approximately $90 \%$ of residents there were farmers) faced countless burdens, such as drought, famine, wars, Turkish invasions, earthquakes and epidemics. Furthermore, the land barons gradually increased taxes, violating the Old Order (stara pravda), ${ }^{10}$ or the legislated amount of dues. Farmers started to organize themselves and the first formal organization (Bauernbund) occurred during a revolt in 1478 in Carinthia, and this was followed by four further large-scale revolts (in 1515, 1573, 1635 and 1713) and around 200 local skirmishes. The Slovenian peasant revolt of 1515 has a special place among similar uprisings, as it was the largest of its kind (encompassing nearly the entirety of Slovenian lands), the longest (five months), and the biggest (at its height it included 80,000 serfs). The revolt began in Gottschee, where Count Jörg von Thurn had acquired a landowner's estate as a security and, with the help of his steward Johannes Stersen, constantly increased farmers' dues and paid no heed to the poverty of his subjects. The farmers united against him and killed both the steward and the count at the end of February or the beginning of March 1515, and from there continued their fight against the nobility. The rebellion spread quickly from Gottschee and, by June 1515, farmers had taken over many castles in Slovenian lands and beyond, driving the nobility out. Emperor Maximillian I stepped in to restore order, sending an army under the command of Jurij Herberstein, who had quashed the revolt by August 1515, punishing the rebels with hanging, beheading or impaling. The nobility's army pillaged and burned villages, while the serfs were handed even higher taxes, along with a socalled punitive tax, levied so as to pay for the damage that the nobles had suffered during the revolt (Grafenauer, 1974, pp. 35-120; Kordiš et al., 2015, pp. 3-29).

\footnotetext{
10 The term Old Order referred to the written and regulative amount of obligations and debts that the serfs had towards the land barons, and it was in place till the end of the Middle Ages, when the barons or castle dwellers, who had received a particular provincial fiefdoms a security, began introducing new taxes (in Slovenian lands this was especially true in the second half of the 15th century). Thus the Old Order in the context of the time did not refer just to a "right", but also "the regular lump-sum tax paid to the feudal lord", as well as to the "old duties", which, according to the farmers' perspective or even the perspective of the era in general, were a right that could not expire or undergo limitation, and which were immutable because they originated from God and were therefore above any secular authority (Grafenauer, 1974, p. 82).
} 


\section{|| Lidija Rezoničnik}

The novel's narrative quite faithfully follows the historical events, placing it within a real chronotope (the year 1515, sites that include villages in Gottschee and the cities of Kočevje and Ljubljana), while the characters are fictional literary subjects intermixed with historical figures. The rebellion's leader, the Gottscheer Hans Jonke from Mösel (Mozelj), along with Jörg Urban from Windischdorf (Slovenska vas) and Mathe König from Altlag (Stari Log), rounds up the peasants and goes to attack the castle of Friedrichstein, where they kill Count Jörg von Thurn, his son, and his steward Johannes Stersen. The Puntars, as the peasants had taken to calling themselves, declared autonomous rule in Gottschee and the rebellion spread throughout Carniola, until it was suppressed at the end of the summer in 1515, with the rebels being punished.

Given its topic, Luther (1943), Mühlberger and Habitzel (2003), and Hladnik (2009) consider Rebellion in der Gottschee a historical novel, a genre whose beginning experts place in the Romantic period (Walter Scott and his novel Waverley, 1814). The "technical" criteria used to make such a classification were also employed in the aforementioned project on the German historical novel, and include text length (at least 150 pages) and a time-frame or chronotope that is far from the period in which the author was born (Mühlberger \& Habitzel, 2003, p. 219). Historical novels do not necessarily feature a single protagonist or hero, but rather centre on historical reality, are recognizable historical period, which the narrator reconstructs from available documentary evidence, while the literary figure (either imaginary or real) merely functions as an intermediary between this and the reader. Although the historical events themselves can be described rather objectively, the way they were experienced is not objectively accessible, which allows the narrator of a historical novel certain flexibility and a subjective dimension (Hladnik, 2009, pp. 21-48; Pavel, 2006, pp. 22-23). In Rebellion in der Gottschee these are primarily essayistic and reflective segments, when the narrator or heroes think about the events, about their own role therein, especially about the beauties of nature and of their farming life, while some heroes and events are fictitious or at least unattested (e.g. Elisabeth Stersen's traitorous aid to the Gottschee rebels, and the death of Jörg von Thurn at Friedrichstein castle).

\section{Slovenians and Gottschee Germans in the Novel Rebellion in der Gottschee}

The chronotope of Rebellion in der Gottschee is set in the beginning of the 16th century in the region of Gottschee, which is inhabited by both Gottschee Germans and Slovenians. The narrative perspective is that of 
the Gottscheers, while the Slovenians (or Slavs) feature less and play the role of the Other in the novel. The novel shows the juxtaposition of the literary image of the Gottscheer culture and ethnicity (self-image or autoimage) alongside that of the Other (the Slovenian; hetero-image), with the method of imagology defining both as portrayals in the given historical moment and given culture. We view and judge the portrayal of the Other from the perspective of our own portrayal, which often forms on the basis of established opposites and which is a mix of emotions and ideas, wherefore it is subjective and cannot be analogous to reality (Pageaux, 2008, pp. 7-63).

\section{The Portrayal of the Gottschee Germans (Self-image/Auto-image)}

The preface to Rebellion in der Gottschee has the narrator summarizing the history of the settling of Germans in Gottschee, before which Kočevska was just an "unsettled old-growth forest". ${ }^{11}$ The Germans began living in a Slavic milieu and, apart from exceptional circumstances, "timidly" avoided close contact (marrying) with their Slavic neighbours, ${ }^{12}$ which in the narrator's opinion contributed to the fact that, of the numerous German settlements in Carniola, this was the only one to maintain a Germanic identity, language and culture. The story of the German settlement in Gottschee is repeated several times in the novel (cf. Rom, 1938, pp. 25, 45, $124,198,227,301)$, with the values of endurance, strength and conviction as displayed by the Gottscheers' ancestors, who cut fertile land out of the ancient forest, ploughed fields, and then as peaceful, God-fearing farmers lived out their days in their new Gottscheer home in harmony with nature.

The most important and most-oft emphasized values of the Gottscheers were God, land, and the homeland of Gottschee. They respect tradition, i.e. the novel describes their customs for religious holidays: All Hallows' Eve, Christmas, the Epiphany, Easter, etc. (cf. Rom, 1938, pp. 68-70, 85, 219231). Their Sunday clothes are portrayed, along with their pilgrimages, traditions for engagement and marriage, and death and funerary rituals (cf. Rom, 1938, pp. 38, 57, 75, 255-257, 265). The gatherings of women and children in the evening hours are mentioned, when they spun wool and recalled old German fairy tales, which the storytellers had tailored over the years to include familiar elements, and they also discussed events in the local Gottscheer environment (cf. Rom, 1938, pp. 101-106); farmer's chores are listed, such as, for example, cutting grass, etc. (cf. Rom, 1938, p.

11 "unbewohnter Urwald" (Rom, 1938, p. 8).

12 “ängstlich vermeiden, sich mit den umliegenden Slawen ehelich zu binden" (Rom. 1938, p. 8). 


\section{Lidija Rezoničnik}

254). The narrator describes the Gottscheers as proud people who maintain their dignity before their master. They show respect, but they do not feel inferior, and they do not excessively subordinate themselves. Nonetheless they abide by the law, and before the rebellion they try all means possible to achieve an understanding with Count von Thurn. Since the Gottschee Germans had the feudal or imperial right to peddle their wares, they were well travelled, visiting foreign regions and cities, although they felt best in the countryside and farming was the work they truly wanted to pursue. For example, when 16-year-old Peterl, brother of Hans Jonke, learns that he will inherit a farm, he excitedly exclaims: "I'm allowed to become a farmer? That's my biggest, my only wish!" ${ }^{13}$ Being attached to the land was also what kept many farmers from actively participating in the peasants' revolt, as pressing, difficult tasks in the fields significantly limited the number of farmers who were willing to wait at the ready in the town of Kočevje. The leaders of the rebellion were the embodiment of willingness to "put the good of all above the good of the individual"14 for the benefit of the community, which they also used to excuse and rationalize the fact that they killed. As they and their families saw murder as a paramount sin, they were able to soothe their conscience only through a long-lasting internal struggle, confession, and pilgrimage. Disagreements within the German Gottscheers also feature in the novel, but these are mostly between Gottscheer farmers and residents of the town of Kočevje, who were merchants. The merchants initially joined the rebellion, but soon plummeting sales and the fact that farmers were leading the revolt caused them to reconsider, whereupon they betrayed the farmers and let the enemy army into the town.

The nobility - the von Thurn family, and the vicedom or provincial representative in Ljubljana, Erasmus Prauenbarth - who themselves were German, look upon them as the Other or as foreigners. In their eyes these are stubborn, thick-skinned rabble-rousers. Only the knight Freiherr von Ungnad, who subdued the Gottschee peasant revolt with his army and who was authorized to punish the rebels, finds out at the trial after Hans Jonke's final speech that he was wrong about the Gottscheers: "He had considered them sycophants and glory hogs, who just incited and deceived their own people. Now he found out that they were men who stood behind whatever they did". ${ }^{15}$

\footnotetext{
13 "Ich darf Bauer werden? Das ist mein größter und einziger Wunsch" (Rom, 1938, p. 317).

14 "Das Wohl der Gemeinschaft steht über dem Wohl des Einzelnen" (Rom, 1938, p. 124).

15 "Für Streber und Ehrgeizlinge, die ihr Volk aufgewiegelt und verführt, hatte er sie gehalten. Nun aber sah er, es waren Männer, die für das einstanden, was sie getan” (Rom, 1938, p. 304).
} 


\section{Portrayal of Slovenians (Hetero-image)}

The novel makes rare mention of Slovenians, and it is not explicitly mentioned in the novel that Slovenians and Gottschee Germans were living in the same villages. The narrator does not use a word based on "Slov-" for them or their language, but rather "windisch/Winde", which along with "wendisch/Wende" in the Middle Ages meant "Slavic" in general. Janez Vajkard Valvasor, for example, uses both terms interchangeably in his The Glory of the Duchy of Carniola to refer to the residents of Carniola. Later the term "Winde" specifically meant Slovenian, while the term "Wende" meant Sorbs or Lusatian Serbs, and the term "Slovenian" became standard usage at the beginning of the 19th century (Lencek, 1990, pp. 93-96). At the end of the 19th and in the 20th century Germans used "Winde/Wende" as a pejorative term for Slovenes or Slavs in general (Čeh Steger, 2017, p. 438).

In one scene, when he contemplates the past of his people, the leader of the Gottschee rebellion, Hans Jonke, reports that the Slovenians observed the Germans who were beginning to settle in Gottschee with disbelief: "Our Slovenian neighbour laughed. He thought the old forest was too poor in quality. German hands shrank the forest and from it made German soil". ${ }^{16}$ The majority of Slovenians in the novel are man servants and servant girls, for instance the trio of Mojka, ${ }^{17}$ Mirko and Iwan ${ }^{18}$ at Friedrichstein castle. The old and heavy Mojka is a faithful handmaid to Miss Helena, wife of nobleman Jörg von Thurn, a Croatian by birth, who secretly admits to feeling better in the company of Slavs than around Germans. Mojka talks a lot, and in everything she does she tries to stay on her lady's good side. They agree that Slovenian servants are better suited to working in the castle than Gottscheers, who are too independent: "[the serf Mattl] is almost the only one of all those Gottscheers who wants to work here for us. They are too proud, those rural oafs, to bow their heads before their masters. We should only bring Slovenians in, as they put up with much more and listen better". ${ }^{19}$ Mojka says of the Slovenes that they are much

\footnotetext{
16 "Der windische Nachbar hatte gelächelt. Ihm war er [der Urwald] zu schlecht erschienen. Da rodeten deutsche Arme und machten deutsches Land aus ihm" (Rom, 1938, p. 227).

17 The Slovenian form of the name is Mojca. The personal name Mojka is used rarely in Slovenian lands. This transcription probably came about as a result of the letter $<\mathrm{c}>$ being pronounced as $/ \mathrm{k} /$ in German.

18 The Slovenian form of the name is Ivan.

19 "[Knecht Mattl] [i] st eh fast der einzige, der von diesen Gottscheern noch bei uns dienen will. Sind zu stolz, diese Bauernklachl, vor ihrer Herrschaft den Buckel zu krümmen. Lauter Windische müssen wir nehmen, die halten viel mehr aus und sind folgsamer" (Rom, 1938, pp. 59,60 ).
} 


\section{|| Lidija Rezoničnik}

more flexible and pliable, and they know how to choose their words so as not to anger their master. For example, the Slovenian servant Mirko quietly, though not without effort, tolerates the abuse that the seven-yearold nobleman's son Jörgel gives him, while it proves too much for the Gottscheer servant Urban, who snaps and punishes Jörgel, which in turn earns him a severe punishment later on (cf. Rom, 1938, pp. 66, 67). Since Count Jörg von Thurn fired all of the Gottscheer servants, only Slovenian servants were left at the castle; however, von Thurn was not completely satisfied with this either, as he does not understand Slovenian, which enrages him. He swears to himself to supply new German servants, but of course not ones from Gottschee, rather ones from Carinthia or Steiermark (cf. Rom, 1938, p. 109). The castle's steward Johannes Stersen (Slovenian Jurij Stržen) does, however, speak Slovenian. The novel tells us about him only that he arrived in Graz as a poor and sickly student, where his future wife Elisabeth's family took care of him. His ethnicity is never defined, but it is clear that he knows Slovenian since he communicates with the Slovenian servants, and furthermore in cases of extreme anger he curses in Slovenian.

Things get lost in translation between the Slovenians and the Gottscheers, e.g. when Hans's fiancée comes to Friedrichstein castle and the Slovenian guard replies to her in broken German: "Don't be home, esteemed sir." It would seem that the Slovenians and Gottscheers do not communicate much among one another and they understand each other poorly as well. During a night-time attack on Ljubljana's castle, where the Gottschee rebels were joined by farmers from other Slovenian regions, they used a war cry - but each in their own language: the Gottscheers cried "For justice and freedom!", while the Slovenians cried "The old order!" ${ }^{21}$ The latter expression, which the narrator says refers to the old rights enjoyed by Slovenian farmers to fixed levels of taxation, makes several appearances in the novel (cf. Rom, 1938, pp. 178, 215, 237), always written in Slovenian and in the Latin script instead of Gothic.

According to the novel, Gottscheers had the biggest role in the peasant revolt of 1515, while the Slovenian residents of the region, who themselves were less than satisfied with the excessive taxes, only rebelled later, after seeing the success of the Gottscheers. Vicedom Prauenbarth is of the opinion that the Slovenians never would have dared to launch a rebellion by themselves: "The Slovenian oafs wouldn't have even made a sound if the burly Germans, those Gottscheers of the old woods, hadn't led them to

\footnotetext{
20 "Nicht zu Hause sein, gnädiger Herr." (Rom, 1938, p. 140).

21 "Für Recht und Freiheit", "Stara pravda” (Rom, 1938, p. 237).
} 
revolt through their example". ${ }^{22}$ When the Gottschee and Slovenian farmers join up to attack Ljubljana, they must contend with several disagreements. Everyone has their own plan to attack Ljubljana's castle and, since they cannot come to a consensus, they attack separately, with the Gottscheers and a handful of Slovenians attacking at night and everybody else during the day. After the defeat of the peasant army in Ljubljana the Slovenian farmers are the first to surrender, while the Gottscheers continue to rebel. The leaders of the rebellion from other regions flee from punishment to Croatia, yet the Gottscheers maintain their revolt and voluntarily accept responsibility and punishment for their actions.

\section{Conclusion}

Slovenians in Rebellion in der Gottschee are presented in the role of not especially determined farmers who easily give up when the going gets rough. The Slovenian rebel leaders, as opposed to their Gottscheer counterparts, do not take responsibility for their actions, but flee instead. The Slovenian farmers are also those who do not agree to the Gottscheers' plans for a joint attack, which is what makes them unsuccessful, and what leads to the rebellion being quashed. As individuals, Slovenes appear in the novel in the role of servants, serfs and handmaids, and their character is subdued, subservient and patient, willing and able to be subordinate to their master. A stereotype of the attentive and obedient Slovenian thus forms, just as in Slovenian author Ivan Cankar's (1876-1918) play Hlapci (The Serfs) from 1910 , one which is widespread as a trope in modern society, especially as an auto-stereotype. The narrator refers to the Slovenians exclusively through the expression "Winde, windisch", where it is not entirely clear whether he is speaking generally of Slavs as a whole (independent of nationalistic tendencies, which were not all that developed in 1515), or specifically of Slovenes.

The portrayal of Slovenians in the novel discussed here is not particularly positive, despite the fact that they are not depicted as the enemy, as they are for instance in the Austrian Rudolf Hans Bartsch's (1873-1952) novel Das deutsche Lied (1912). It is interesting that both novels show similarities in how they describe the Germans living in Slovenian lands, emphasizing the benefits the Germans brought, such as making the land fertile, as well as similarly portraying their lives among their Slovenian neighbours, etc. (cf. Čeh Šteger, 2017). The Gottschee Germans in Rebellion in der Gottschee are

\footnotetext{
22 "Die windischen Klacheln hätten sich nicht gemuckst, wenn nicht diese vierschrötigen Deutschen, diese Urwaldmenschen aus der Gottschee, mit solchem Beispiele vorausgegangen wären" (Rom, 1938, p. 234).
} 


\section{| Lidija Rezoničnik}

strong, experienced and educated farmers (the narrator goes to great lengths in the preface to explain that there is also an extraordinarily high level of intelligence in comparison to their small number), with an important past. They keep their traditions, as well as their faith in God, land and homeland. They abide by the rules, but their pride prevents them from bowing to every pointless demand issued by their master. Despite being mere farmers, they are quite capable of impressive feats and undertakings, as well as of fair and just rule.

People in Gottschee lived in mixed, Slovenian-German villages; until the 19th century and the advent of nationalist thought (after 1848), language was not a reflection of ethnic belonging, but simply a means of communication. Many people were bilingual, and negative preconceptions about one another were not so widespread or prevalent (Moric, 2016b, pp. 89-99). The events in the novel do not show such a state, but rather give the impression that at the beginning of the 16th century Slovenes and Gottschee Germans lived separately, had trouble communicating with one another, and did not have any special interest in forming bonds withone another. By depicting things this way the author does not show a true image of real relations before the revolt of 1515, but rather emphasizes the nationalistic side of things, which during the novel's writing was at its very peak. Elevating the settlement of the Germans in Gottschee to an almost heroic and strong, positive portrayal thereof was written in the nationalistic spirit to promote national feelings among Gottscheers, those small groups among the Slavs. This image in fact was not purely and uncompromisingly German, as hundreds of years of life in Gottschee and interaction with Slovenes (Slavs) had led to the development of a unique culture and language. Karl Rom showed the image of the austere and hearty Gottschee farmer within the context of a historical novel, which in the first half of the 20th century was again an important genre, portraying national heroes and the glorious history of a given nation, and thus serving as the perfect tool for consolidating national awareness.

\section{References}

Čeh Steger, J. (2017). Podoba Slovencev v Bartschevem romanu Das deutsche Lied. Slavistična revija, 65(3), 433-445.

Dolinar, K., \& Knop, S. (2003). Kranjska. In Leksikon Cankarjeve založbe (p. 536). Ljubljana: Cankarjeva založba.

Ferenc, M. (2005). Kočevska, pusta in prazna: Nemško jezikovno območje na Kočevskem po odselitvi Nemcev. Ljubljana: Modrijan.

Ferenc, T. (2002). Nemci na Slovenskem med drugo svetovno vojno. In D. Nećak 
(Ed.), Zbornik: "Nemci” na Slovenskem 1941-1955 (pp. 145-190). Ljubljana: Znanstveni inštitut Filozofske fakultete.

Grafenauer, B. (1974). Boj za staro pravdo v 15. in 16. stoletju na Slovenskem (pp. 35-120). Ljubljana: DZS.

Hladnik, M. (2009). Slovenski zgodovinski roman. Ljubljana: Znanstvena založba Filozofske fakultete Univerze v Ljubljani.

Janko, A., \& Otorepec, B. (1989). Gotica. In M. Javornik (Ed.), Enciklopedija Slovenije (pp. 317-318). Ljubljana: Mladinska knjiga.

Kordiš, I., Petrovič, M., \& Jerbič Perko, V. (2015). Leukhup leukhup woga gmaina: 500 let slovenskega kmečkega upora 1515. Kočevje: Pokrajinski muzej Kočevje.

Lencek, R. (1990). Note: The terms Wende - Winde, Wendisch - Windisch in the historiographic tradition of the Slovene lands. Slovene Studies, 12(1), 93-97.

Luther, A. (1943). Deutsche Geschichte in deutscher Erzählung. Leipzig: Verlag Karl W. Hiersemann.

Moric, A. (2014). Domovina globoko v srcu. Kočevski Nemci v diaspori. Etnolog, 24(75), 81-104.

Moric, A. (2016a). Nesnovna kulturna dediščina kočevskih Nemcev: Včeraj in danes, med staro in novimi domovinami. In R. Andres, L. Rezoničnik et al. (Eds.), Mednarodno znanstveno srečanje mladih humanistov: Slovanski jeziki na stičišču kultur (pp. 103-116). Ljubljana: Zveza društev Slavistično društvo Slovenije.

Moric, A. (2016b). Slovenski Nemci v diaspori (PhD thesis). Fakulteta za družbene vede, Univerza v Ljubljani, Ljubljana.

Moric, A. (2017). Vitrine spomina/Showcases of memory/Vitrinen des Gedenkens. Stara Cerkev: Zavod Putscherle, center za raziskovanje, kulturo in ohranjanje kulturne dediščine.

Mühlberger, G., \& Habitzel, K. (2003). “Widerkehr des Gleichen?” oder: Einige Bemerkungen zu einer strukturellen Poetik des deutschsprachigen historischen Romans: Mit einem Anhang zum deutschsprachigen historischen Roman bis 1945 in den Grenzen des heutigen Slowenien. In M. Hladnik (Ed.), Slovenski roman (pp. 213-220). Ljubljana: Center za slovenščino kot drugi/tuji jezik pri Oddelku za slovenistiko Filozofske fakultete Univerze v Ljubljani.

Neugebauer, W., \& Schwarz, P. (2005). Der Wille zum aufrechten Gang: Offenlegung der Rolle des BSA bei der gesellschaftlichen Integration ehemaliger Nationalsozialisten (pp. 213-233). Vienna: Czernin Verlag.

Österreichische Nationalbibliothek. (n.d.). Retrieved September 20, 2017, from https:// www.onb.ac.at/

Pageaux, D.-H. (2008). Imagološke razprave. Ljubljana: Institutum Studiorum Humanitatis, Fakulteta za podiplomski humanistični študij.

Pavel, T. (2006). The novel in search of itself: A historical morphology. In F. Moretti (Ed.), The novel (pp. 3-31). Princeton, NJ: Princeton University Press.

Projekt Historischer Roman. (n.d.). Retrieved September 10, 2017, from https:// www.uibk.ac.at/germanistik/histrom/cgi/wrapcgi.cgi?wrap_config=hr_bu_all. cfg\&nr=53960 


\section{Lidija Rezoničnik}

Reisp, B. (n.d.). Janez Vajkard Valvasor. In Slovenska biografija. Retrieved October 10, 2017, from http://www.slovenska-biografija.si/oseba/sbi759993/

Rom, K. (1938). Rebellion in der Gottschee. Wien: Amalthea Verlag.

\section{Podoba Slovencev in kočevskih Nemcev v zgodovinskem romanu Rebellion in der Gottschee}

Prispevek preučuje književnost kočevskih Nemcev, nekdanjih prebivalcev slovenske pokrajine Kočevske. V prvem delu kratko predstavi zgodovino in književno ustvarjalnost kočevskih Nemcev, nato pa se osredotoča na zgodovinski roman Rebellion in der Gottschee (Upor na Kočevskem), ki ga je napisal Karl Rom. Roman je izšel leta 1938 v nemškem jeziku in opisuje veliki kmečki upor v Sloveniji (v tedanji Kranjski), ki se je odvijal leta 1515. Upor so organizirali prebivalci Kočevske proti nasilnemu zemljiškemu gospodu in je bil kmalu tudi zatrt. Na podlagi imagologije članek analizira podobo Slovanov (Slovencev) in Germanov (kočevskih Nemcev) v romanu.

Ključne besede: Kočevski Nemci, Upor na Kočevskem, Karl Rom, zgodovinski roman, veliki kmečki upor 1515, imagologija, podoba lastnega, podoba tujega.

\section{Wizerunek Słoweńców i Niemców z Kočevja w powieści historycznej Rebellion in der Gottschee}

Artykuł analizuje literaturę Niemców z Kočevja, będących niegdyś mieszkańcami tego słoweńskiego regionu. W pierwszej części została przedstawiona historia oraz twórczość literacka koczewskich Niemców, następnie uwaga skupia się na powieści historycznej Rebellion in der Gottschee (Bunt w Kočevju) autorstwa Karla Roma. Powieść ukazała się w 1938 roku w języku niemieckim, opisuje zaś wielki chłopski bunt wSłowenii (w ówczesnej Krainie) z roku 1515. Mieszkańcy Kočevja wzniecili bunt przeciwko okrutnemu właścicielowi ziemskiemu, jednak został on bardzo szybko stłumiony. Wpisując się w perspektywę imagologiczną, 
artykuł bada wizerunek Słowian (Słoweńców) i Germanów (Niemców z Kočevja) przedstawionych w powieści.

Słowa kluczowe: Niemcy z Kočevja, Kočevje, Karl Rom, powieść historyczna, rewolta chłopska 1515, imagologia, autowizerunek, heterowizerunek.

Przekład z języka słoweńskiego, Maciej Falski

\section{Note}

Lidija Rezoničnik, Department of Slavistics and Department of Comparative Literature and Literary Theory, Faculty of Arts, University of Ljubljana, Ljubljana.

Lidija.Rezonicnik@ff.uni-lj.si

The preparation of the article was self-funded by the author.

No competing interests have been declared. 